\title{
Kainate Receptor-Induced Retrograde Inhibition of Glutamatergic Transmission in Vasopressin Neurons
}

\author{
Valérie D. J. Bonfardin, ${ }^{1,2,3}$ Dionysia T. Theodosis, ${ }^{1,2}$ Arthur Konnerth, ${ }^{3}$ and Stéphane H. R. Oliet ${ }^{1,2}$ \\ ${ }^{1}$ Inserm, Unité 862, Neurocentre Magendie, 33077 Bordeaux, France, ${ }^{2}$ Université de Bordeaux, 33077 Bordeaux, France, and ${ }^{3}$ Institute of Neuroscience, \\ Technical University of Munich, 80802 Munich, Germany
}

Presynaptic kainate receptors (KARs) exert a modulatory action on transmitter release. We here report that applications of agonists of GluK1-containing KARs in the rat supraoptic nucleus has an opposite action on glutamatergic transmission according to the phenotype of the postsynaptic neuron. Whereas glutamate release was facilitated in oxytocin (OT) neurons, it was inhibited in vasopressin (VP) cells. Interestingly, an antagonist of GluK1-containing KARs caused an inhibition of glutamate release in both OT and VP neurons, revealing the existence of tonically activated presynaptic KARs that are positively coupled to transmitter release. We thus postulated that the inhibition of glutamate release observed with exogenous applications of GluK1 agonists on VP neurons could be indirect. In agreement with this hypothesis, we first showed that functional GluK1-containing KARs were present postsynaptically on VP neurons but not on OT cells. We next showed that the inhibitory effect induced by exogenous GluK1 receptor agonist was compromised when BAPTA was added in the recording pipette to buffer intracellular $\mathrm{Ca}^{2+}$ and block the release of a putative retrograde messenger. Under these conditions, GluK1-containing KAR agonist facilitates glutamatergic transmission in VP neurons in a manner similar to that observed for OT neurons and that resulted from the activation of presynaptic GluK1 receptors. GluK1-mediated inhibition of glutamate release in VP neurons was also blocked by a $\kappa$-opioid receptor antagonist. These findings suggest that activation of postsynaptic GluK1-containing KARs on VP neurons leads to the release of dynorphin, which in turn acts on presynaptic $\kappa$-opioid receptors to inhibit glutamate release.

\section{Introduction}

The hypothalamo-neurohypophysial system comprises the supraoptic (SON) and the paraventricular (PVN) nuclei. The SON is composed of magnocellular neurons that project their axons into the neurohypophysis in which they release oxytocin (OT) and vasopressin (VP). Whereas OT is essential for reproductive functions, VP is involved in body fluid homeostasis. In addition to their secretion in the general circulation, OT and VP are also released from the somato-dendritic compartment (Moos et al., 1984; Pow and Morris, 1989) to enable magnocellular neurons to control their own firing discharge and synaptic activity. Other substances costored with OT and VP and coreleased from the somato-dendritic compartment are also likely to play a role in regulating SON neuron excitability. This is the case for dynorphin (Watson et al., 1982; Whitnall et al., 1983) whose action on postsynaptic $\kappa$-opioid receptors is an important feedback signal for the autoregulation of phasic activity in VP neurons (Brown et al., 1998; Brown and Bourque, 2004).

\footnotetext{
Received June 15, 2011; revised Nov. 18, 2011; accepted Nov. 22, 2011.

Author contributions:V.D.J.B., D.T.T., S.H.R.O., and A.K. designed research; V.D.J.B. performed research; V.D.J.B., D.T.T., and S.H.R.O. analyzed data; V.D.J.B. and S.H.R.O. wrote the paper.

This work was supported by grants from Inserm, Fondation pour la Recherche Médicale, and the Human Frontier Science Program. V.D.J.B. was supported by studentships from the Ministère de l'Education Nationale de la Recherche et de la Technologie and the Fondation pour la Recherche Médicale. The confocal microscopy was performed in the Bordeaux Imaging Center, Bordeaux. We thank Philippe Legros, Christel Poujol, and Laure Malicieux for their technical assistance. We thank Drs. Christophe Mulle and Paulo Pinhero for helpful discussions.

Correspondence should be addressed to Stéphane H. R. Oliet, Inserm, Unité 862, Neurocentre Magendie, 146, rue Léo Saignat, 33077 Bordeaux, France. E-mail: stephane.oliet@inserm.fr.

DOI:10.1523/JNEUROSCI.3017-11.2012

Copyright $\odot 2012$ the authors $\quad 0270-6474 / 12 / 321301-10 \$ 15.00 / 0$
}

Glutamate is the major excitatory transmitter in this brain region. It acts on different types of ionotropic and metabotropic receptors located postsynaptically and presynaptically. Glutamate mediates fast synaptic transmission through three classes of ionotropic receptor: NMDA, AMPA, and kainate receptors (KARs). The family of KARs is composed of five different genes coding for the subunits GluK1, GluK2, GluK3, GluK4, and GluK5 (for review, see Bettler and Mulle, 1995; Chittajallu et al., 1999). Activation of presynaptic KARs can regulate the release of glutamate or GABA in a positive or negative manner, thereby playing a key role in modulating the excitability of neuronal networks (Pinheiro and Mulle, 2006). These receptors are also present postsynaptically (Huettner, 2003; Lerma, 2003) in which they were shown to participate to the synaptic response (Castillo et al., 1997; Vignes and Collingridge, 1997). Evidences from in situ hybridization studies in the SON indicate an absence of GluK2, GluK3, and GluK4 mRNA, low levels of GluK1 mRNA in some neurons, and high levels of GluK5 in all neurons (van den Pol et al., 1994; Eyigor et al., 2001). In the magnocellular subdivision of the PVN, GluK1 mRNA labeling matches the distribution of VP neurons (Herman et al., 2000). Although the presence of functional KARs in the SON has been established recently on GABAergic terminals (Bonfardin et al., 2010), their presence on glutamatergic afferents and on the magnocellular neurons themselves and their roles remain to be determined.

In the present study, we established for the first time the presence of functional GluK1-containing KARs on glutamatergic terminals in the SON. We showed that activation of GluK1-containing KAR agonist facilitated and inhibited transmission in OT and 
VP neurons, respectively. The inhibition of glutamate release after GluK1 activation in VP neurons was compromised when intracellular postsynaptic $\mathrm{Ca}^{2+}$ was buffered with ethylenedioxybis (o-phenylenenitrilo)tetraacetic acid, 2,2'-(ethylenedioxy)dianiline$N, N, N^{\prime}, N^{\prime}$-tetraacetic acid (BAPTA) or by antagonizing $\kappa$-opioid receptors. These data suggest that activation of postsynaptic GluK1 receptors on VP neurons causes the $\mathrm{Ca}^{2+}$-dependent somatodendritic release of dynorphin, which acts in a retrograde manner to inhibit glutamate release.

\section{Materials and Methods}

Slice preparation. Experiments were performed on acute hypothalamic slices obtained from Wistar male rats of 2-3 months old. Rats were anesthetized with isoflurane and decapitated. All experiments were conducted with respect to the European directives and the French Law on animal experimentation (Authorization 33 0004). The brain was quickly removed and placed in ice-cold artificial CSF (ACSF) saturated with 95\% $\mathrm{O}_{2}$ and $5 \% \mathrm{CO}_{2}$. Coronal slices $(300 \mu \mathrm{m})$ were cut with a vibratome (Leica VT1000S) from a block of tissue containing the hypothalamus. Slices at the level of the SON were then hemisected along the midline and allowed to recover for at least $1 \mathrm{~h}$ at $33^{\circ} \mathrm{C}$ in a submerged chamber containing ACSF before recording. After $30 \mathrm{~min}$ of recovery at room temperature, a hemislice was then transferred and submerged in a recording chamber in which it was continuously perfused $(1-2 \mathrm{ml} / \mathrm{min}$ ) with ACSF at room temperature. The composition of the ACSF was as follows (in mM): $123 \mathrm{NaCl} ; 2.5 \mathrm{KCl}, 1 \mathrm{Na}_{2} \mathrm{HPO}_{4}, 26.2 \mathrm{NaHCO}_{3}, 1.3$ $\mathrm{MgCl}_{2}, 2.5 \mathrm{CaCl}_{2}, 10$ glucose, and 0.1 picrotoxin, $\mathrm{pH} 7.4$ (295-300 $\mathrm{mOsm} / \mathrm{kg}$ ).

Patch-clamp recording. Magnocellular neurons in the SON were identified visually using infrared differential interference contrast microscopy (Olympus BX50). The patch-clamp recording pipettes (3-5 M $\Omega$ ) were filled with a solution containing the following (in $\mathrm{mM}$ ): $130 \mathrm{CsCl}, 10$ $\mathrm{NaCl}, 10$ HEPES, 5 QX-314, 1 EGTA, 0.1 and $\mathrm{CaCl}_{2}$, adjusted to $\mathrm{pH}$ 7.1-7.3 with $\mathrm{CsOH}(292-296 \mathrm{mOsm} / \mathrm{kg})$. In some experiments, BAPTA $(20 \mathrm{~mm})$ was added in the intracellular solution. Biocytin $(0.2 \%)$ was included in the pipette solution for post hoc identification of the recorded cells. Membrane currents were recorded using an Axopatch-1D amplifier (Molecular Devices); signals were filtered at $2 \mathrm{kHz}$ and digitized at $5 \mathrm{kHz}$ via a DigiData 1440 A interface (Molecular Devices). Series resistance (6-15 M $\Omega$ ) was monitored online, and cells were excluded from data analysis if a $>20 \%$ change occurred during the course of the experiment. All cells were held at $-70 \mathrm{mV}$ in voltage-clamp mode. Spontaneous unitary synaptic currents (miniatures) obtained in the presence of tetrodotoxin (TTX; $0.5 \mu \mathrm{M}$ ) were stored on videotape via a pulse-code modulator (Neurodata) and analyzed offline with Axograph (Molecular Devices). Detection was achieved using a sliding template, and $\geq 200$ events were analyzed for each cell in each condition. All drugs were bath applied, except glutamate $(3 \mathrm{~mm})$ that was applied locally as a puff (10 ms) (Castillo et al., 1997; Cossart et al., 1998) using a glass electrode connected to a picospritzer and positioned within $100 \mu \mathrm{m}$ in the $x-y$-axis and $\sim 15 \mu \mathrm{m}$ in the $z$-axis of the recorded neuron. For the experiments performed in the presence of AMPA and NMDA receptor antagonists, the pipette was brought closer $(60 \mu \mathrm{m}$ in the $x-y$-axis) because the responses generated under these conditions were of smaller amplitude.

The data, reported as means \pm SE, were compared statistically with the paired or unpaired Student's $t$ test. Amplitude and frequency distributions of the miniatures were compared using the nonparametric Kolmogorov-Smirnov test. Significance was assessed at $p<0.05$.

Drugs. All drugs were bath applied. Appropriate stock solutions were made and diluted with ACSF just before application. QX-314 chloride, a voltage-gated sodium channel blocker (Alomone Labs), was diluted directly in the patch solution. The drugs used were the following: biocytin, glutamicpyruvic transminase (GPT), philanthotoxin-433 tris (trifluoroacetate) salt (PhTx), BAPTA, (S)-2-aminopentanedioic acid [L-glutamic acid (glutamate)], picrotoxin, NBQX, 6,7-dinitroquinoxaline-2,3-dione (DNQX), TTX, (RS)-2-amino-3-(3-hydroxy-5-tert-butylisoxazol-4-yl) propanoic acid (ATPA), (S)-1-(2-amino-2-carboxyethyl)-3-(2-carboxybenzyl) py- rimidine-2,4-dione (UBP302), D-(-)-2-amino-5-phosphonopentanoic acid (D-AP-5), 4-(8-methyl-9H-1,3-dioxolo[4,5-h][2,3]benzodiazepin-5yl)-benzenamine hydrochloride (GYKI52466), GYKI53655, 17,17'-(dicy-

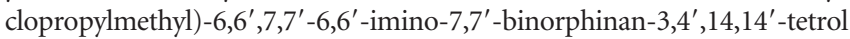
dihydrochloride (nor-BNI), 8-cyclopentyl-1,3-dipropylxanthine (DPCPX), $N$-(piperidin-1-yl)-5-(4-iodophenyl)-1-(2,4-dichlorophenyl)-4-methyl-1 $H$-pyrazole-3-carboxamide (AM251), (2S)-1-[[(2R,3S)-5-chloro-3-(2chlorophenyl)-1-[(3,4-di methoxyphenyl)sulfonyl]-2,3-dihydro-3hydroxy-1 H-indol-2-yl] carbonyl]-2-pyrrolidinecarboxamide (SR49059), and D-Phe-Cys-Tyr-D-Trp-Orn-Thr-Pen-Thr- $\mathrm{NH}_{2}$, (disulfide bridge: 2-7) (CTOP). Apart from biocytin, PhTx, GPT, BAPTA, glutamate, and CTOP, which were obtained from Sigma, and GYKI53655, kindly provided by Dr. Christophe Mulle (CNRS, UMR 5091, Bordeaux, France), all the drugs were obtained from Tocris Bioscience. As described previously (Min et al., 1998) GPT (from porcine heart, $115 \mathrm{kDa}$ ) was dialyzed for $3 \mathrm{~h}$ with a $10 \mathrm{kDa}$ cutoff membrane (Slide-A-Lyser; Pierce Chemical) before the experiments.

Neuron identification. After recording, magnocellular neurons filled with biocytin $(0.2 \%)$ were identified further by immunocytochemistry. At the end of the recording period, slices were fixed by immersion in $4 \%$ paraformaldehyde and $0.15 \%$ picric acid $(2 \mathrm{~h}$, room temperature and during 2 or $3 \mathrm{~d}$ at $4^{\circ} \mathrm{C}$ ). The biocytin was visualized after incubation (overnight at $4^{\circ} \mathrm{C}$ ) with streptavidin-conjugated 7-amino-4-methylcoumarin-3-acetic acid (AbCys) diluted 1:200. Sections containing biocytin-positive neurons were then incubated for $7 \mathrm{~d}\left(\right.$ at $\left.4^{\circ} \mathrm{C}\right)$ in a mixture of a monoclonal mouse antibody raised against VP (diluted 1:20,000; gift from V. Geenen, University of Liege, Liege, Belgium; for production and specificity, see Moll et al., 1988) and a polyclonal rabbit serum raised against OT (diluted 1:4000; gift from T. Higuchi, University of Fukui, Fukui, Japan; for production and specificity, see Higuchi et al., 1983). Immunoreactivities were then revealed by incubation in a mixture with goat anti-mouse Igs conjugated to fluorescein isothiocyanate (FITC; AbCys) (diluted 1:1600) and goat anti-rabbit Igs conjugated to Texas Red (AbCys) (diluted to 1:500, overnight at $4^{\circ} \mathrm{C}$ ). All antibodies were diluted in a solution of TBS containing $0.25 \%$ BSA and $2 \%$ Triton X-100. Controls including omission of primary antibodies and incubation with inappropriate secondary antibodies yielded no specific immunolabeling. Slices were mounted in Vectashield (AbCys) and examined with a confocal microscope (Leica DMR TCS SP2 AOBS on an upright stand, using objective HCX Plan Apo CS 63×, numerical aperture 1.40). The lasers used were argon (488 nm), green helium-neon (543 nm), and a diode laser $(405 \mathrm{~nm})$. Images were acquired using Leica TCS software with a sequential mode to avoid interference between each channel. All confocal images are projections of 20 consecutive optical sections $(0.5 \mu \mathrm{m})$. Contrast/brightness enhancement was done in parallel on obtained stacks using Adobe Photoshop 8.0 (Adobe Systems).

\section{Results}

\section{Target-cell specificity of KAR action on glutamate release in the SON}

Previous studies described the action of various presynaptic receptors on glutamate terminals in the SON (Kabashima et al., 1997; Kombian et al., 1997; Schrader and Tasker, 1997; Liu et al., 1999; Oliet and Poulain, 1999; Price and Pittman 2001; Hirasawa et al., 2004), but no particular attention was paid to KARs. Except when stated otherwise, we identified VP and OT cells by post hoc immunostaining throughout the all study. To address this issue, we recorded miniature EPSCs (mEPSCs) in the presence of TTX and picrotoxin $(100 \mu \mathrm{M})$ to block action potentials and $\mathrm{GABA}_{\mathrm{A}}$ receptor-mediated currents, respectively. Activation of KARs with kainate (KA; $300 \mathrm{nM}$ ) yielded two types of opposite effects on glutamate transmission according to the cell phenotype (Fig. 1). In immuno-identified VP neurons $(n=8)$, KA decreased the mean frequency from $1.4 \pm 0.2$ to $0.9 \pm 0.1 \mathrm{~Hz}(-35.5 \pm 2.6 \%$; $p<0.05)$ but not the amplitude $(-18.4 \pm 1.8 \mathrm{pA}$ in control conditions vs $-17.7 \pm 1.6 \mathrm{pA}$ in the presence of $\mathrm{KA} ;-4.0 \pm$ $2.4 \% ; p>0.05)$ of mEPSCs. Conversely, KA had an opposite action on OT neurons, increasing the frequency of mEPSCs from 
A1 VP neuron
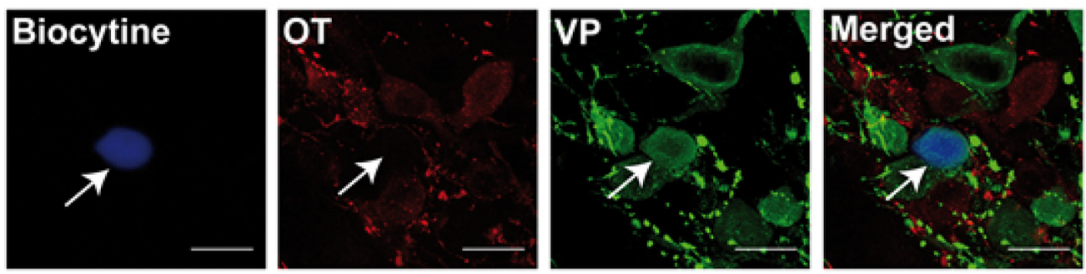

A2

control

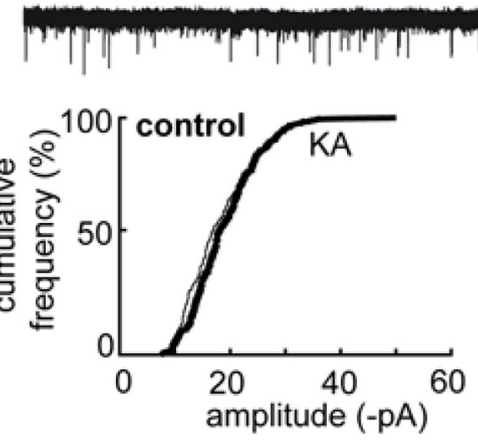

B1 OT neuron
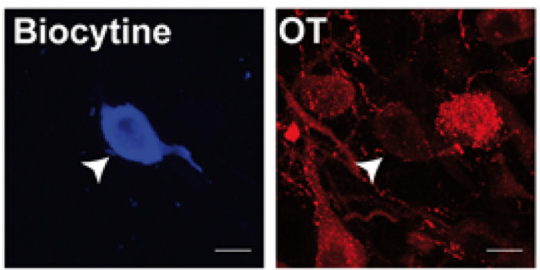

B2

control
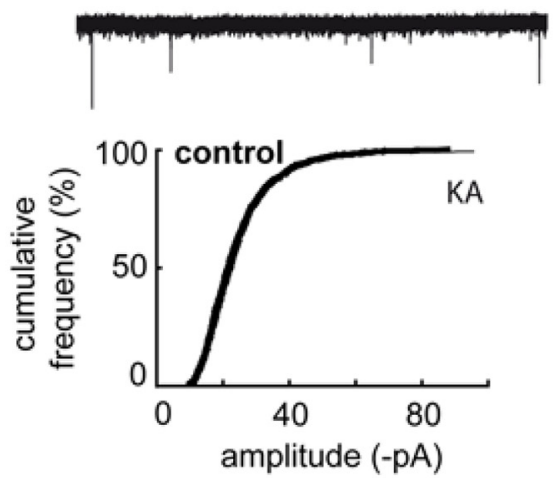

C

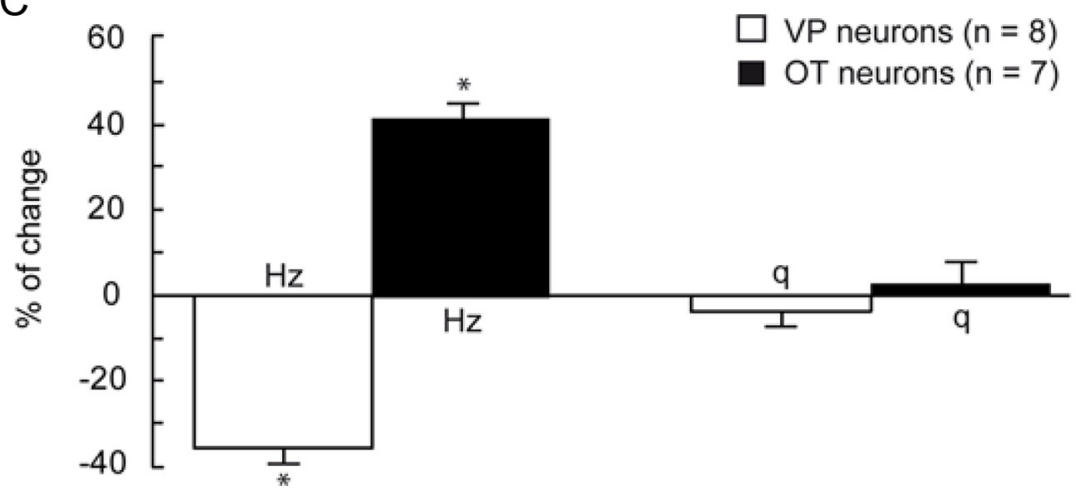

KA 300 nM
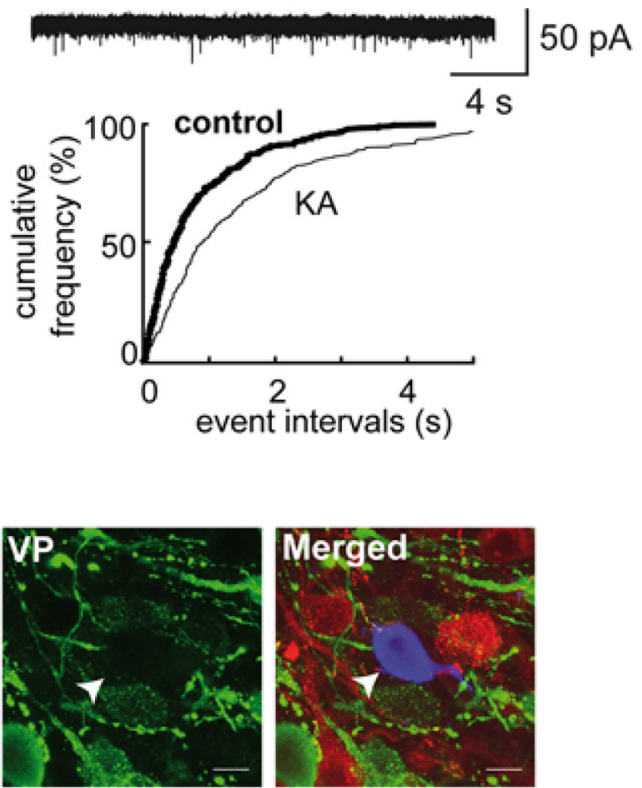

KA 300 nM
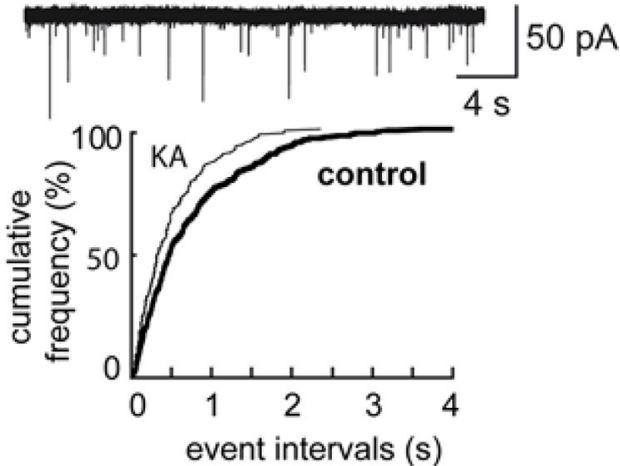

event intervals (s)

$\square$ VP neurons $(\mathrm{n}=8$ )

OT neurons $(\mathrm{n}=7)$ 
A
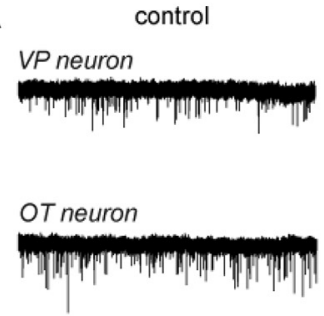

B
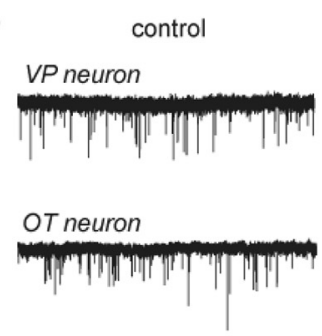

ATPA $1 \mu \mathrm{M}$
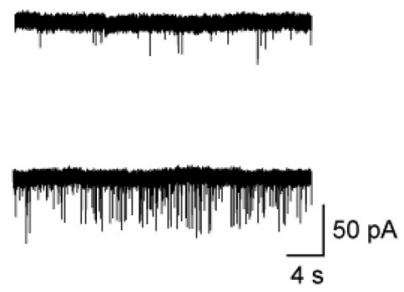

UBP302 $10 \mu \mathrm{M}$
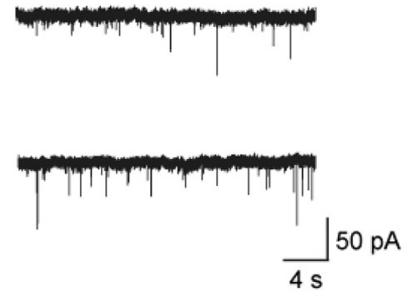

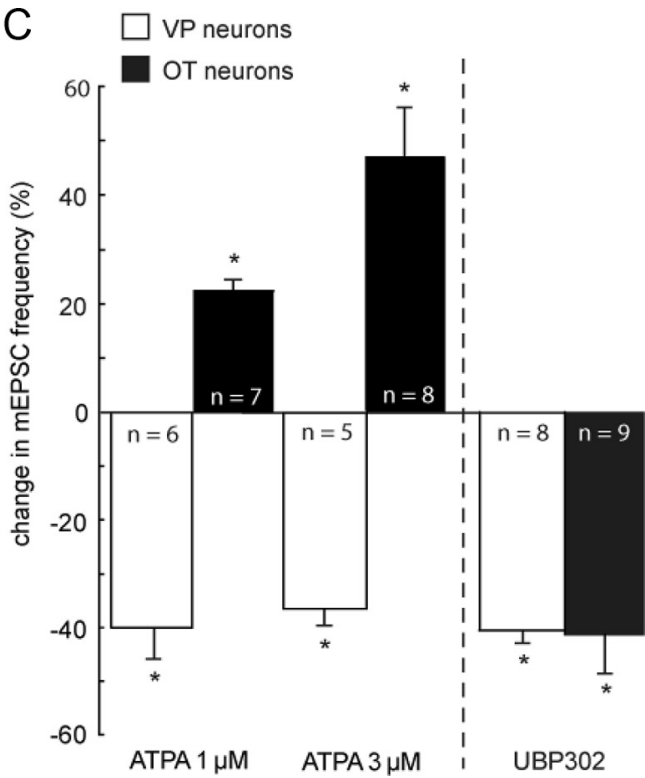

Figure 2. KAR action on VP and OT neurons involve GluK1-containing KARs. A, Traces showing mEPSC activity recorded before (control) and during bath application of ATPA, a selective agonist of GluK1-containing KARs in VP and OT neurons. B, Traces showing mEPSC activity recorded before (control) and during bath application of UBP302, a selective antagonist of GluK1-containing KARs in VP and OT neurons. C, Summary histograms illustrating the percentage change in mean frequency (in hertz) of mEPSCsinduced by 1 and $3 \mu \mathrm{M}$ ATPA (left part of the histogram) as well as by UBP302 (right part of the histogram) in VP (white bars) and OT (black bars) neurons. ${ }^{*} p<0.05$, significant difference from control.

$0.8 \pm 0.2$ to $1.2 \pm 0.2 \mathrm{~Hz}(+41.2 \pm 2.4 \% ; p<0.05 ; n=7)$ without affecting their amplitude $(+2.0 \pm 4.6 \% ; p>0.05 ; n=7)$ (Fig. 1C).

These results indicate that KA is acting presynaptically to decrease or increase the probability of glutamate release on VP and OT neurons, respectively.

\section{GluK1 receptors mediated the opposite action of KA on} glutamatergic transmission on VP and OT neurons

We tested whether such opposite actions of KA on OT and VP cells were mediated through specific subtypes of receptors. To this end, we used the GluK1-containing KAR selective agonist ATPA (Clarke et al., 1997; Bortolotto et al., 1999). As expected, we found that, in VP neurons, ATPA $(1 \mu \mathrm{M})$ decreased the frequency of mEPSC frequency from $0.8 \pm 0.3$ to $0.5 \pm 0.2 \mathrm{~Hz}$ $(-40.1 \pm 5.4 \% ; p<0.05)$ but not their amplitude $(-16.6 \pm 1.2$ vs $-16.4 \pm 1.4 \mathrm{pA} ;-1.9 \pm 3.8 \% ; n=6 ; p>0.05)$ of mEPSCs (Fig. $2 A, C$ ). Conversely, in OT neurons, ATPA significantly and$$
\leftarrow
$$

(Figure legend continued.) VP, and OT. All confocal images are projections of 20 consecutive optical sections $(0.5 \mu \mathrm{m})$. Scale bars, $20 \mu \mathrm{m}$. A2, Traces (top) obtained from the cell shown in A1 showing mEPSC activity recorded before (control) and during bath application of KA. Corresponding cumulative plots (bottom) of amplitude (left) and event-interval (right) distributions before (control; thick line) and during (KA; thin line) KA applications. KA induced a rightward shift of the event-interval distribution, in agreement with a decrease in mEPSC frequency. The amplitude of these events was not affected. $\boldsymbol{B}$, Example of a recording obtained from an $0 \mathrm{~T}$ neuron. B1, The recorded cell (white arrows) displayed fluorescence for biocytin (blue) (first panel) and immunoreactivity for VP (green) (third panel) but not for OT (red) (second panel). The right panel shows superimposed fluorescence for biocytin, VP, and $0 T$. Scale bars, $20 \mu \mathrm{m}$. $B 2$, Traces obtained from the cell shown in $\boldsymbol{B} 1$ showing $\mathrm{mEPSC}$ activity recorded before (control) and during bath application of KA. Corresponding cumulative plots of amplitude (left) and event-interval (right) distributions before (control; thick line) and during (KA; thin line). KA induced a leftward shift of the event-interval distribution, in agreement with an increase in mEPSC frequency. The amplitude of these events was not affected. C, Summary histogram illustrating the percentage change in mean frequency (in hertz) and amplitude (q) of mEPSCs induced by KA in VP (white bars) and in 0 T neurons (black bars). ${ }^{*} p<0.05$, significant difference from control.
}

reversibly increased mEPSC frequency from $1.8 \pm 0.5$ to $2.2 \pm$ $0.6 \mathrm{~Hz}(+22.7 \pm 1.9 \% ; n=7 ; p<0.05)$, without affecting the amplitude of these events $(-24.9 \pm 2.0$ vs $-26.2 \pm 2.5 \mathrm{pA}$; $+4.9 \pm 4.6 \% ; p>0.05$ ) (Fig. $2 A, C$ ). Increasing ATPA concentrations to $3 \mu \mathrm{M}$ yielded changes in mEPSC frequency similar in magnitude to those obtained in response to KA $(-38.4 \pm 3.0 \%$; $p<0.05 ; n=5$ for VP neurons and $+50.20 \pm 9.2 \% ; p<0.05 ; n=$ 8 for OT neurons) (Fig. 2C), without affecting the amplitude of these events $(-6.7 \pm 1.1$ and $-6.3 \pm 4.7 \% ; p>0.05$ for $\mathrm{VP}$ and OT respectively; $p>0.05)$.

To confirm the involvement of GluK1 receptors in the effects mediated by KA applications, we tested the effects of KA and ATPA in the presence of UBP302, a selective antagonist of Gluk1containing receptors (More et al., 2004). Under these conditions, KA (300 nM) no longer affected mEPSC frequency in both cell types $(+1.1 \pm 13.6 \%, n=9$ and $-12.5 \pm 6.2 \%, n=7$ for VP and OT respectively; $p>0.05$; data not shown) Similarly, ATPAmediated inhibition and facilitation of mEPSC frequency in VP and OT neurons at 1 and $3 \mu \mathrm{M}$ was completely blocked by UBP302 $(-3.4 \pm 11.5 \%, n=7$ and $-9.9 \pm 10.3 \%, n=7$ for VP and OT, respectively; $p>0.05$ for ATPA at $1 \mu \mathrm{M})(-8.1 \pm 7.9 \%$, $n=6$ and $-5.7 \pm 8.3 \%, n=7$ for VP and OT, respectively; $p>$ 0.05 for ATPA at $3 \mu \mathrm{M}$ ) (data not shown).

Interestingly, application of UBP302 $(10 \mu \mathrm{M})$ by itself induced in both VP and OT neurons a reversible decrease in mEPSC activity that was associated with a significant reduction in the frequency of these unitary events from $0.8 \pm 0.2$ to $0.5 \pm 0.2 \mathrm{~Hz}$ $(-41.0 \pm 2.0 \%, n=8)$ and from $1.1 \pm 0.3$ to $0.5 \pm 0.2 \mathrm{~Hz}$ $(-42.1 \pm 7.4 \%, n=9)$ for VP and OT cells, respectively $(p<$ $0.05)$. The amplitude of mEPSCs was not affected $(-6.5 \pm 4.9$ and $-9.8 \pm 5.0 \%$ for VP and OT, respectively; $p>0.05$ ) (Fig. $2 B, C)$. These findings indicate that ambient glutamate exerts a tonic action on presynaptic GluK1 receptors to facilitate glutamate release. To confirm this finding, slices were incubated with GPT ( $5 \mathrm{U} / \mathrm{ml}$ ), an enzymatic glutamate scavenger, to reduce the ambient level of the excitatory amino acid (Min et al., 1998). In 


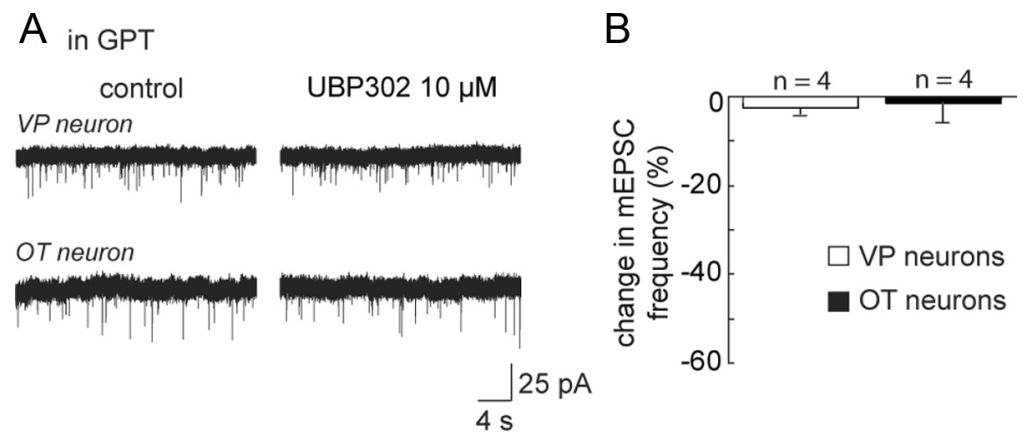

Figure 3. Reducing ambient glutamate levels impairs the tonic activation of KARs. $A$, Example of recording obtained in slices treated with GTP $(5 \mathrm{U} / \mathrm{ml})$ and pyruvate $(2 \mathrm{~mm})$ to reduce the concentration of extracellular glutamate. Traces show mEPSC activity recorded before (control) and during bath application of UBP302 in a VP neuron (top traces) and an OT neuron (bottom traces). $\boldsymbol{B}$, Summary histograms illustrating the percentage change in mean frequency (in hertz) of mEPSCs induced by UBP302 in VP (white bars) and OT (black bars) neurons under conditions in which ambient glutamate was degraded with GPT.

the presence of GPT and 2 mM pyruvate, UBP302 no longer induced a significant change in mEPSC frequency in VP $(-2.4 \pm$ $1.0 \% ; n=4)$ and OT $(-1.1 \pm 3.6 \% ; n=4, p>0.05)$ neurons (Fig. 3). As expected, in slices incubated with GPT in the absence of pyruvate, which is required for the enzymatic action of GPT, UBP302 decreased mEPSC frequency in OT $(n=3)$ and VP $(n=$ 3) neurons to the same extent as observed without GPT (data not shown).

That a GluK1 antagonist inhibits glutamate release makes sense for OT magnocellular neurons because we showed that activation of these receptors were facilitating glutamatergic transmission. However, the finding that the same effect is observed in VP neurons is in discrepancy with the inhibition of mEPSC activity induced by the activation of GluK1 receptors with exogenous agonists. One possibility to account for this discrepancy could be that the inhibition observed in VP neurons with exogenous agonists involves GluK1 receptors distinct from those activated by ambient glutamate that mediate the tonic facilitation of glutamate release.

\section{Postsynaptic KARs in OT and VP neurons}

The inhibitory effect of KAR on transmitter release could reflect an indirect action such as already reported in the striatum (Chergui et al., 2000). In that study, activation of postsynaptic KAR triggered the release of a retrograde signal from the somatodendritic compartment and the subsequent activation of presynaptic receptors. To explore this possibility in VP neurons, we first tested whether we could detect postsynaptic GluK1 receptormediated responses in VP neurons. To this end, we recorded currents evoked by local puff applications of $3 \mathrm{~mm}$ glutamate in both OT and VP neurons. These recordings were obtained in the presence of TTX and picrotoxin $(100 \mu \mathrm{M})$ to block action potentials and $\mathrm{GABA}_{\mathrm{A}}$ receptor-mediated currents, respectively. These evoked currents of very large amplitude were primarily reduced when blocking NMDA and AMPA receptors (Fig. 4). In magnocellular neurons that were not identified, glutamate-evoked currents were inhibited by $90.1 \pm 1.5 \%(n=8$; $p<0.05)$ with GYKI52466 $(100 \mu \mathrm{M})$ and D-AP-5 $(50 \mu \mathrm{M})$, by $85.9 \pm 2.2 \%(n=$ $7 ; p<0.05)$ with NBQX $(1 \mu \mathrm{M})$ and D-AP-5 and by $81.8 \pm 3.3 \%$ $(n=12 ; p<0.05)$ with GYKI53655 $(50 \mu \mathrm{M})$ and D-AP-5 $(50 \mu \mathrm{M})$. The reductions observed in these three different conditions were not statistically different from each other $(p>0.05)$, and none of these mixtures of antagonists were able to completely inhibit the glutamate-evoked responses in all the recorded cells. The remaining current $(9.9 \pm 1.5 \%$ for GYKI52466; $14.1 \pm 2.2 \%$ for NBQX at $1 \mu \mathrm{M}$ and $19.7 \pm 3.3 \%$ for GYKI53655 at $50 \mu \mathrm{M}$; percentage of control values) (Fig. 4A,B) was abolished by DNQX at 20 $\mu \mathrm{M}$, in agreement with the contribution of postsynaptic KARs to these responses.

To assess the involvement of GluK1 receptors in these responses, we next investigated the action of UBP302 $(10 \mu \mathrm{M})$ in the presence of D-AP-5 $(50 \mu \mathrm{M})$ and NBQX $(1 \mu \mathrm{M})$. Whereas the currents mediated by KARs in OT neurons were not significantly affected by the GluK1 antagonist (101.3 $\pm 4.2 \% ; n=7 ; p>0.05)$, those elicited in VP cells were reduced by $52.6 \pm 4.5 \%(n=8 ; p<0.05)$ (Fig. 4C,D). We next assessed whether the GluK1 receptors located on VP neurons were permeable to $\mathrm{Ca}^{2+}$ (Lauri et al., 2003; Pinheiro et al., 2007; Mathew and Hablitz., 2008; Sun et al., 2009). In agreement with this hypothesis, we observed that a blocker of $\mathrm{Ca}^{2+}$-permeable AMPA/KAR, PhTx (3 $\left.\mu \mathrm{M}\right)$ (Fletcher and Lodge, 1996), inhibited glutamate-evoked response obtained in the presence of D-AP-5 $(50 \mu \mathrm{M})$ and NBQX $(1 \mu \mathrm{M})$ to the same extent as UBP302 (43.1 $\pm 5.4 \% ; n=7 ; p<0.05)$, whereas it has no effect in OT neurons $(98.1 \pm 3.1 \% ; n=11 ; p>0.05)$ (Fig. 5). We also found that, in VP neurons, the presence of PhTx prevented the inhibitory action of UBP302 on these puff responses (94.6 \pm $0.7 \% ; n=7 ; p>0.05)$, as expected if the receptors blocked by PhTx were GluK1-containing KARs. These data demonstrate that VP neurons, but not OT cells, express functional postsynaptic GluK1-containing KARs that are permeable to $\mathrm{Ca}^{2+}$.

\section{KAR-mediated inhibition of glutamate release depends on postsynaptic intracellular $\mathrm{Ca}^{2+}$}

The presence of GluK1-containing KARs on VP neurons agrees with a model in which KAR-mediated inhibition of glutamate release is indirect, involving the postsynaptic production of a retrograde messenger. Because the GluK1 receptors on VP neurons are $\mathrm{Ca}^{2+}$ permeable, their activation could cause an elevation of intracellular $\mathrm{Ca}^{2+}$ under voltage-clamp conditions sufficient to trigger the release of a retrograde signal. If true, buffering intracellular $\mathrm{Ca}^{2+}$ in VP neurons should prevent KAR-mediated inhibition of glutamate release. To this end, we included in our recording pipette $20 \mathrm{mM}$ BAPTA and tested the action of ATPA ( 1 $\mu \mathrm{M})$ on mEPSCs. Under these conditions, ATPA increased mEPSC activity in both VP and OT neurons (Fig. 6A, B). In VP neurons, mEPSC frequency was augmented by $+22.5 \pm 2.9 \%$ $(n=4 ; p<0.05)$, whereas the amplitude of those events was unaffected $(-4.7 \pm 10.0 \% ; p>0.05)$. In OT neurons, ATPA facilitated mEPSC frequency by $+29.8 \pm 3.8 \%(n=7 ; p<0.05)$ without modifying quantal size $(-3.3 \pm 3.3 \% ; p>0.05)$. These results indicated that preventing postsynaptic $\mathrm{Ca}^{2+}$ elevation blocked the inhibiting effect of GluK1-containing KARs on glutamate release in VP neurons without affecting their facilitating action on glutamatergic terminals in OT and VP cells.

\section{Postsynaptic GluK1-containing receptor activation induces a $\kappa$-opioid receptor-mediated presynaptic inhibition}

Our data suggest that GluK1-containing KAR activation in VP neurons induced the $\mathrm{Ca}^{2+}$-dependent release of a retrograde messenger that inhibits glutamate release. In SON neurons, ele- 
A

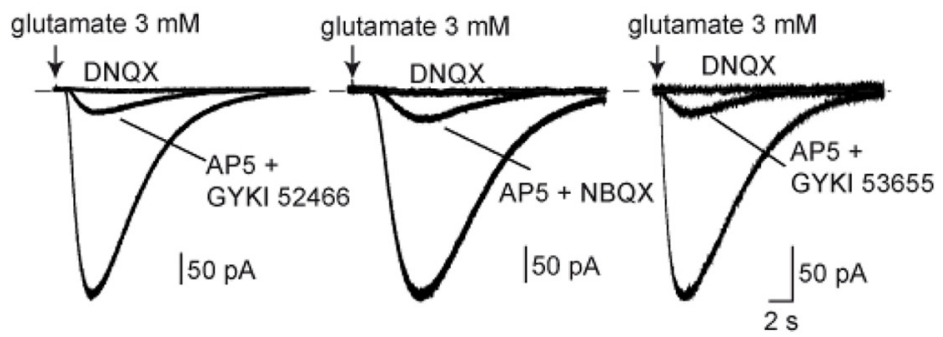

B

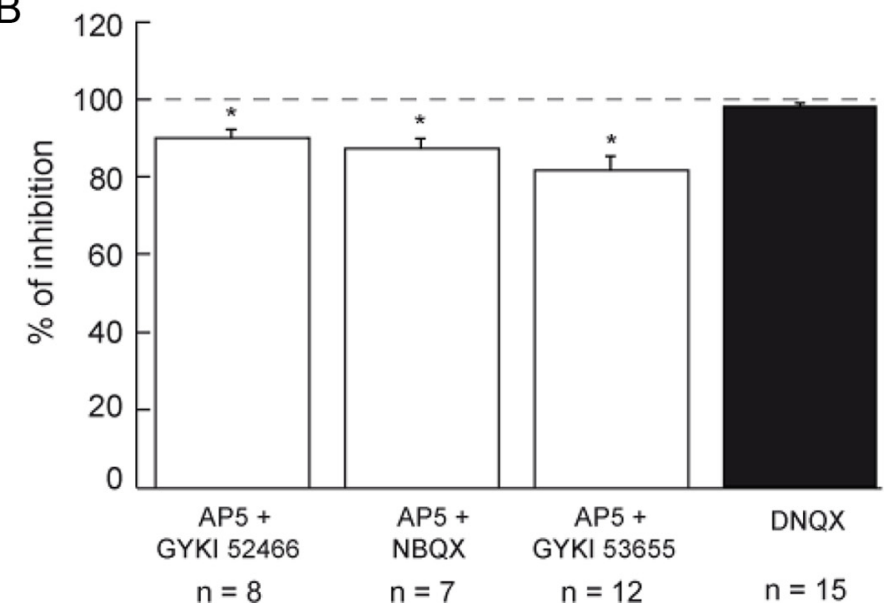

C in $A P 5+N B Q X 1 \mu M$

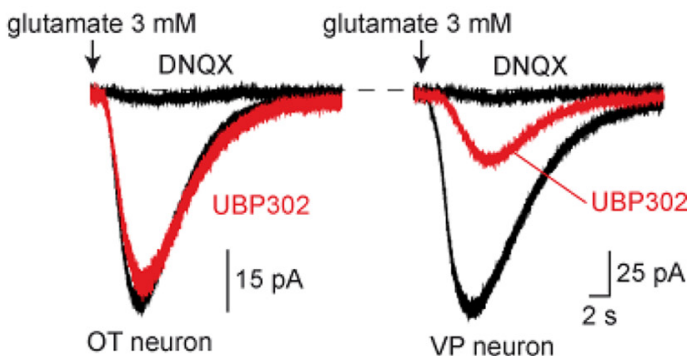

$\mathrm{D}$

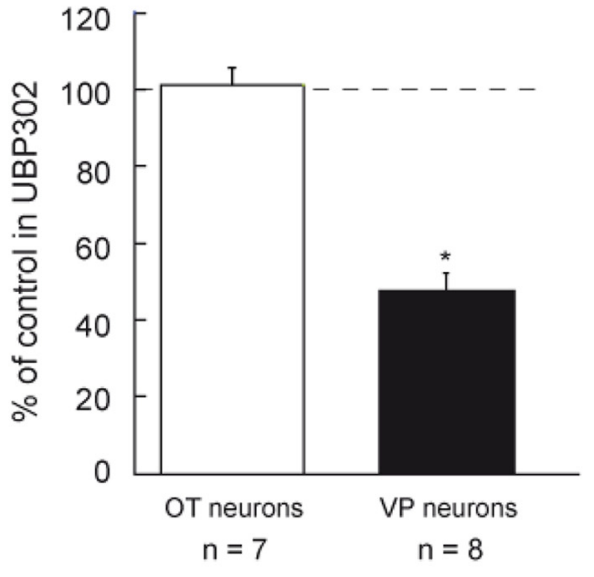

Figure 4. Postsynaptic KARs on VP and $0 \mathrm{~T}$ neurons. $A$, Puff applications of glutamate $(3 \mathrm{~mm}, 10 \mathrm{~ms})$ (arrow) in the presence of TTX (0.5 $\mu \mathrm{m})$ yielded large inward currents that were primarily inhibited with D[scAP]-AP-5 (50 $\mu \mathrm{m}$ ) and GYKI52466 (100 $\mu \mathrm{m}$; left), NBQX (1 $\mu \mathrm{m}$; middle), or GYKI53655 (50 $\mu \mathrm{m}$; right). The remaining responses were completely abolished with DNQX (20 $\mu \mathrm{m})$. $\boldsymbol{B}$, Summary histogram illustrating the percentage of inhibition of the glutamate-evoked currents induced by the different antagonists used in $\boldsymbol{A} .{ }^{*} p<0.05$, significant difference from control. $\boldsymbol{C}$, Examples of glutamate-evoked responses obtained in a $0 \mathrm{~T}$ (left) and a VP (right) neuron in the presence of TTX (0.5 $\mu \mathrm{M}), \mathrm{D}[\mathrm{scAP}]-\mathrm{AP}-5(50 \mu \mathrm{M})$, and NBQX (1 $\mu \mathrm{M})$. Whereas a subsequent application of UBP302 (10 $\mu \mathrm{m})$ (red trace) did not further inhibit the response obtained in the $0 \mathrm{~T}$ neuron, it significantly reduced that induced in the VP cells. In both cases, the remaining currents were abolished with DNQX $(50 \mu \mathrm{M})$. D, Summary histogram illustrating the differential effect of UBP302 (percentage of control values) on glutamate-evoked currents obtained in 0T (white bars) and VP (black bars) neurons in the presence of TTX, D[sCAP]-AP-5, and NBQX. ${ }^{*} p<0.05$, significant difference from control.

$\mathrm{A}_{\text {in } A P 5+N B Q X 1 \mu M}$
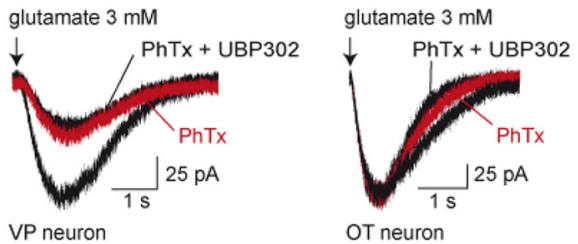

OT neuron
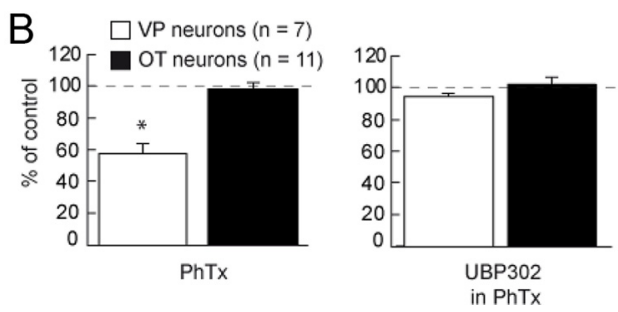

Figure 5. Postsynaptic $\mathrm{Ca}^{2+}$-permeable KARs on VP neurons. $A$, Puff applications of glutamate (3 mM, $10 \mathrm{~ms})$ (arrow) in the presence of TTX (0.5 $\mu \mathrm{m})$, D[sCAP]-AP-5 (50 $\mu \mathrm{m})$, and NBQX (1 $\mu \mathrm{M}$ ) yielded large inward current in both VP (left) and OT (right) neurons. Application of PhTx (red traces) to block $\mathrm{Ca}^{2+}$-permeable KARs primarily inhibited the current in VP but not in OT cells. Subsequent application of UBP302 did not further inhibit the response in VP neurons and had no effect in OT cells. B, Summary histogram illustrating the percentage of control values of the glutamate-evoked currents in the presence of $\mathrm{PhTx}$ (left) and in the presence of UBP302 and $\mathrm{PhTx}$ (right). ${ }^{*} p<0.05$, significant difference from control. vations of $\mathrm{Ca}^{2+}$ trigger the somato-dendritic exocytosis of granules of secretion (Moos et al., 1984; Shibuya et al., 1998; Ludwig et al., 2002; de Kock et al., 2003). In VP neurons, granules of secretion contain various neuromodulators, such as VP and dynorphin. VP acts postsynaptically on $\mathrm{V}_{\text {la }}$ receptors to inhibit AMPA receptor-mediated current amplitude (Hirasawa et al., 2003). Because we never detected changes in mEPSC size, we can rule out the possibility that VP is the retrograde signal acting on glutamatergic terminals. We thus tested the possibility that the retrograde messenger was dynorphin. ATPA was applied in the presence of nor-BNI, a selective $\kappa$-opioid receptor antagonist (Portoghese et al., 1987). Surprisingly, ATPA no longer inhibited mEPSC activity of VP neurons in its presence because the frequency of these events was increased by $37.1 \pm 3.8 \%(n=8 ; p<0.05)$. The action of ATPA on mEPSCs in OT neurons was unaffected by nor-BNI $(+35.3 \pm 9.2 \% ; n=5 ; p<0.05)$ (Fig. $6 C, D)$. This finding establishes that activation of GluK1-containing KARs on VP neurons triggers the release of dynorphin that acts retrogradely on $\kappa$-opioid receptors to inhibit glutamate release.

To ensure that the indirect action of KARs on glutamatergic transmission in VP cells did not involve other signaling molecules like endocannabinoids, VP, adenosine, or an action of dynorphin on $\mu$-opioid receptors, we assessed the action of ATPA in the presence of a mixture of antagonists, including AM251 (5 $\mu \mathrm{M})$, SR49059 $(10 \mu \mathrm{M})$, DPCPX (100 nM), and CTOP (1 $\mu \mathrm{M})$. Under such conditions in which $\mathrm{CB}_{1}, \mathrm{~V}_{1 \mathrm{a}}, \mathrm{A}_{1}$, and $\mu$-opioid receptors 
A
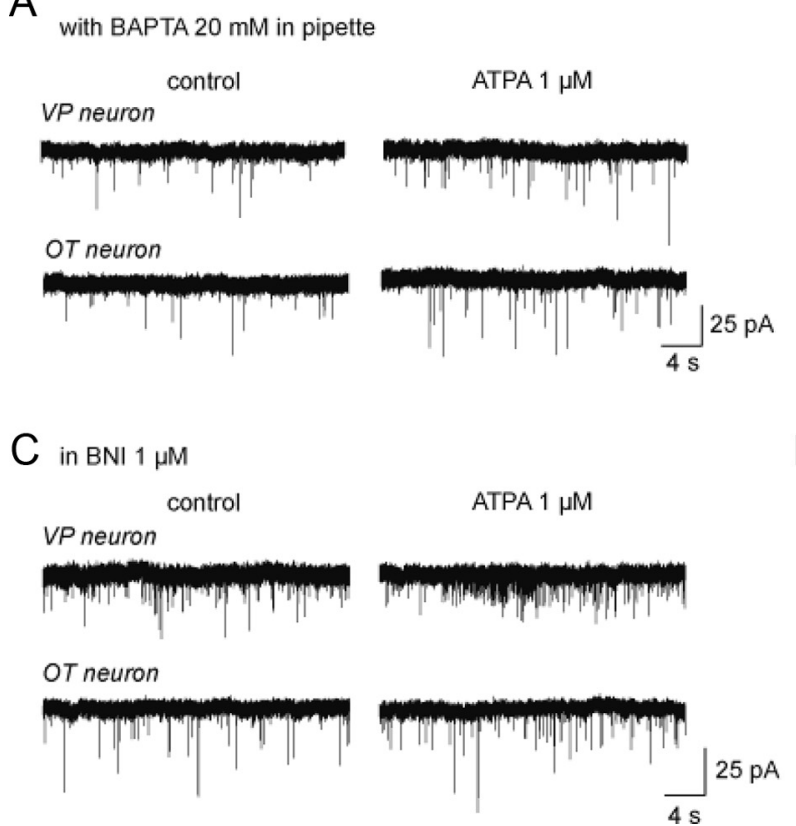

B

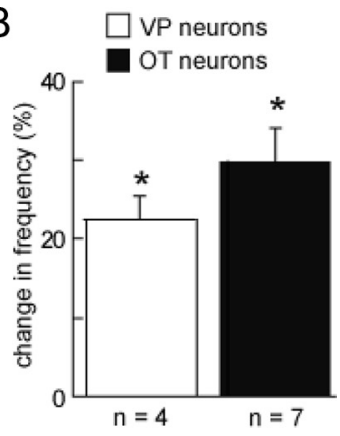

D

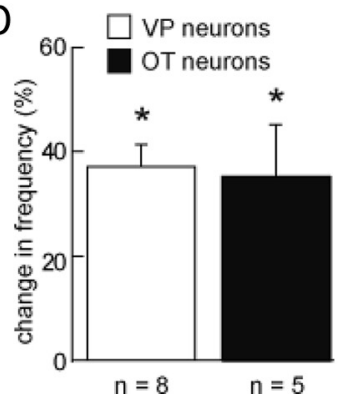

Figure 6. KAR-mediated inhibition of glutamate release on VP neurons involves $\kappa$-opioid receptors. $\boldsymbol{A}$, Examples of mEPSC activities recorded from a VP (top races) and an OT (bottom traces) neuron before (control) and during bath application of ATPA in the presence of BAPTA (20 mm) in the patch pipette. $\boldsymbol{B}$, Summary histogram illustrating the effect of ATPA on mEPSC frequency in VP (white bars) and OT (black bars) neurons under conditions in which BAPTA was present in the recording patch pipette. ${ }^{*} p<0.05$, significant difference from control. $\boldsymbol{C}$, Traces showing mEPSC activity in a VP and an OT neuron recorded before (control) and during bath application of ATPA in the presence of nor-BNI, a selective antagonist of $\kappa$-opioid receptors, in the bath. $\boldsymbol{D}$, Summary histogram illustrating the effect of ATPA on mEPSC frequency in VP (white bars) and OT (black bars) neurons under conditions in which nor-BNI was present in the bath. ${ }^{*} p<0.05$, significant difference from control.

were antagonized, ATPA still had an inhibitory action on mEPSC frequency in VP neurons $(-30.3 \pm 4.0 \% ; n=9 ; p<0.05)$ and a facilitatory effect on OT cells $(+29.8 \pm 6.3 ; n=6 ; p<0.05)$ (data not shown).

The presence of presynaptic $\kappa$-opioid receptors on glutamatergic terminals was next determined by investigating the action of a selective $\kappa$-opioid agonist, U69593 ( $N$-methyl-2-phenyl- $N$ [(6R,8S,9S)-9-pyrrolidin-1-yl-1-oxaspiro[4.5] decan-8-yl] acetamide) $(1 \mu \mathrm{M})$, on mEPSCs (Iremonger and Bains, 2009). Activating $\kappa$-opioid receptors inhibited mEPSC frequency by $36.8 \pm 5.7 \%(n=$ $7 ; p<0.05)$ and by $28.2 \pm 3.1 \%(n=5 ; p<0.05)$ for VP and OT neurons, respectively (Fig. $7 A, B$ ). These changes in mEPSC activity were not accompanied by variations in quantal size $(-5.0 \pm 5.1 \%$, $p>0.05$ for VP neurons; $-7.6 \pm 6.8, p>0.05$ for OT cells), indicative of a presynaptic site of action. To rule out the possibility that the $\kappa$-opioid receptor agonist acted indirectly, we repeated these experiments in the presence of BAPTA $(20 \mathrm{~mm})$ within the recording pipette. This manipulations did not affect the inhibitory action of 1 $\mu \mathrm{M}$ U69593 on mEPSC frequency in VP $(-47.2 \pm 6.8 \% ; n=5 ; p<$ $0.05)$ and in OT neurons $(-25.6 \pm 4.1 \% ; n=5$; $p<0.05)$ (Fig. $7 C, D)$.

\section{Discussion}

We here report for the first time the presence of functional GluK1containing KARs on glutamatergic inputs impinging on OT and VP neurons of the SON. These presynaptic KARs are activated by ambient glutamate, thereby maintaining a tonic facilitation of glutamate release. We also established for the first time the presence of postsynaptic KARs on both OT and VP neurons. Interestingly, only VP neurons express functional GluK1-containing KARs permeable to $\mathrm{Ca}^{2+}$ whose activation induces the $\mathrm{Ca}^{2+}$-dependent release of dynorphin that diffuses retrogradely to inhibit glutamate release. This inhibition overcomes the facilitation of glutamatergic transmission mediated by the tonic activation of presynaptic GluK1 receptors and could thus serve as a negative feedback mechanism, enabling VP neurons to control their own excitability.

\section{Presynaptic GluK1 receptors are positively coupled to glutamate release in the SON}

As reported in other brain structures (for review, see Pinheiro and Mulle, 2006), presynaptic KARs present on glutamatergic inputs impinging on OT and VP neurons are positively coupled to transmitter release. These receptors contain GluK1 as revealed by the use of ATPA and UBP302 that are selective agonist and antagonist for this subunit, respectively. In OT neurons, ATPA and KA increased mEPSC frequency without affecting quantal amplitude, an effect that was entirely blocked by UBP302. For VP neurons, ATPA and KA caused an inhibition of glutamatergic transmission. This inhibitory action, which results from the activation of postsynaptic GluK1 receptors, was prevented by including BAPTA in the patch pipette or by blocking $\kappa$-opioid receptors. Under these conditions, ATPA now induces a facilitation of glutamatergic transmission in VP neurons similar to that observed in OT cells and in agreement with the presence of presynaptic GluK1 receptors positively coupled to glutamate release. In VP neurons, ATPA increased mEPSC frequency by $37.1 \pm 3.8 \%(n=8)$ in the presence of nor-BNI and by $22.5 \pm$ $2.9 \%(n=4)$ with BAPTA in the patch pipette. We propose that these two manipulations affect the activation of $\kappa$-opioid presynaptic receptors, through a direct action for nor-BNI and by preventing retrograde release of dynorphin for BAPTA, thereby revealing the KAR-mediated presynaptic facilitation of glutamatergic transmission. The difference between the actions of nor-BNI and BAPTA can be explained by many mechanisms. Whereas nor-BNI blocks all $\kappa$-opioid receptors, BAPTA will inhibit dynorphin release only from the recorded neuron VP neuron, leaving open the possibility that dynorphin originating and diffusing from neighboring VP cells still impacts glutamatergic transmission. This could explain a reduced facilitation in BAPTA compared with nor-BNI. Another possibility is that BAPTA does not completely prevent dynorphin release in the entire dendritic tree of the recorded VP neurons because of an incomplete intracellular diffusion. Interestingly, UBP302 by itself caused a similar inhibitory effect in miniature activity in both OT and VP neurons, indicating that these presynaptic receptors are activated by ambient glutamate, thereby maintaining a positive tone on glutamate release. In agreement with this result, degrading extracellular glutamate with GPT blocked the inhibitory effect of UBP302 on mEPSCs. The more likely explanation for this positive coupling between GluK1 receptors and glutamate release is the permeation of $\mathrm{Ca}^{2+}$ ions through these receptors or the membrane depolar- 
ization that would be associated with their activation. In both cases, it would lead to $\mathrm{Ca}^{2+}$ entry and an increased release probability.

Indirect inhibitory action of KARs on glutamatergic inputs to VP neurons As mentioned above, application of ATPA inhibited rather than facilitated mEPSC frequency in VP neurons. Buffering intracellular $\mathrm{Ca}^{2+}$ in the postsynaptic compartment prevented this effect and unmasked the facilitating action of presynaptic GluK1 receptors on glutamate release. That a postsynaptic manipulation prevented the presynaptic inhibition of transmitter release induced by ATPA argues in favor of an indirect mechanism. Such a process was reported previously in the striatum (Chergui et al., 2000) in which it involved the activation of postsynaptic KARs and the subsequent somato-dendritic release of adenosine acting retrogradely on presynaptic $A_{2 A}$ receptors to inhibit GABAergic transmission. A similar mechanism thus appears to be triggered in VP neurons when postsynaptic $\mathrm{Ca}^{2+}$-permeable Gluk1containing KARs are activated, leading to the $\mathrm{Ca}^{2+}$-dependent release of a retrograde signal. Our data, however, do not allow us to assess whether the entry of $\mathrm{Ca}^{2+}$ through GluK1-containing KARs is sufficient by itself to induce the release of dynorphin or whether other mechanisms, such as $\mathrm{Ca}^{2+}$ release from intracellular stores, also contribute to this process (Lauri et al., 2003; Mathew and Hablitz, 2008; Scott et al., 2008).

In VP neurons, postsynaptic $\mathrm{Ca}^{2+}$ elevation could cause the possible release of several retrograde messengers, including endocannabinoids, adenosine, dynorphin, and VP (Kombian et al., 1997; Oliet and Poulain 1999; Di et al., 2003; Brown and Bourque, 2004). In VP neurons, blocking adenosine $A_{1}$, $\mathrm{CB}_{1}, \mathrm{~V}_{1 \mathrm{a}}$, and $\mu$-opioid receptors did not affect the inhibitory action of ATPA on $\mathrm{EEPSC}$, ruling out a role for these receptors. Conversely, the selective $\kappa$-opioid receptor antagonist nor-BNI prevented the ATPA-induced inhibition of mEPSCs. These data demonstrate that the retrograde signal originating from VP neurons is a $\kappa$-opioid receptor agonist that is very likely to be dynorphin. Directly activating $\kappa$-opioid receptors with the selective agonist U69593 mimicked the inhibitory effect of ATPA on glutamatergic transmission observed in VP neurons. Interestingly, this effect was observed on VP and OT cells, indicating that glutamatergic inputs impinging on both cell types express $\kappa$-opioid receptors. That the inhibition of glutamate release mediated by U69593 was unaffected when BAPTA was present in the patch pipette rules out an indirect action of this agonist and strongly suggest that the $\kappa$-opioid receptors are located presynaptically. The conditions under which the $\kappa$-opioid receptors located on excitatory synapses impinging on OT neurons are endogenously activated and their functions are presently unknown.

The $\mathrm{Ca}^{2+}$-dependent exocytosis of dynorphin from VP neuron dendrites has been documented previously (Brown and Bourque, 2004). It was shown that dynorphin was acting postsynaptically to modulate ionic conductance, thereby finetuning the phasic activity of these neuroendocrine cells
(Brown and Bourque, 2004). Our data thus suggest that dynorphin also acts presynaptically to inhibit glutamate release. The mechanism by which $\kappa$-opioid receptor activation leads to a reduction in glutamate release probability is presently unknown. Stimulation of these receptors, which belong to the family of the G-protein-coupled receptor, could lead to the activation of $\mathrm{K}^{+}$conductance and consequently to an hyperpolarization of the nerve terminals.

Blocking the indirect inhibitory effect of KARs on glutamatergic transmission with intracellular BAPTA or nor-BNI in the bathing medium revealed a positive coupling of presynaptic Gluk1-containing KARs with glutamate release in VP neurons. This finding suggests that the direct presynaptic facilitation attributable to GluK1 receptor activation and the inhibition attributable to activation of presynaptic $\kappa$-opioid receptors coexist. It is very likely that the inhibitory effect mediated by $\kappa$-opioid receptor activation overcome that caused by the presynaptic KARs.

\section{Physiological relevance}

The release of OT and VP from nerve terminals in the neurohypophysis depends on the electrical activity of magnocellular neurons located in the SON and PVN. This activity is itself primarily influenced by excitatory inputs originating from hypothalamic and extrahypothalamic regions. Modulation of glutamatergic transmission to VP and OT neurons will greatly impact the firing rate of these neurons, and, consequently, their secretory activities. The activation by ambient glutamate of GluK1-containing KARs on glutamatergic terminals would facilitate the release of the excitatory amino acid, thereby promoting the occurrence of EPSPs and the firing of action potentials in both OT and VP neurons. This positive glutamatergic tone on magnocellular neurons could contribute to the secretion 
of OT and VP in the bloodstream occurring under basal conditions of neurosecretion.

The physiological conditions under which the postsynaptic KARs are activated remain to be determined. It is likely that basal release of glutamate is not sufficient to activate these receptors as revealed by the absence of tonic stimulation by ambient glutamate. A more massive release of glutamate, such as occurring during strong and persistent activation of excitatory inputs, is a condition that is more likely to cause stimulation of these postsynaptic KARs. In OT neurons, this activation will lead to membrane depolarization and would thus favor action potential firing. In VP neurons, activation would lead to membrane depolarization as well. In addition, stimulation of GluK1-containing KARs would indirectly inhibit glutamate release, thereby reducing the glutamatergic drive onto these cells. This process could thus serve to reduce the impact of excitatory inputs on VP neuron firing, enabling these cells to develop a more autonomous activity. This could be important for the rhythmic phasic activity displayed by VP neurons in response to physiological stimulation, such as dehydration or hemorrhage, which is believed to depend on both intrinsic membrane properties and extrinsic synaptic influence (Israel et al., 2010).

\section{References}

Bettler B, Mulle C (1995) Review: neurotransmitter receptors. II. AMPA and kainate receptors. Neuropharmacology 34:123-139.

Bonfardin VD, Fossat P, Theodosis DT, Oliet SH (2010) Glia-dependent switch of kainate receptor presynaptic action. J Neurosci 30:985-995.

Bortolotto ZA, Clarke VR, Delany CM, Parry MC, Smolders I, Vignes M, Ho KH, Miu P, Brinton BT, Fantaske R, Ogden A, Gates M, Ornstein PL, Lodge D, Bleakman D, Collingridge GL (1999) Kainate receptors are involved in synaptic plasticity. Nature 402:297-301.

Brown CH, Bourque CW (2004) Autocrine feedback inhibition of plateau potentials terminates phasic bursts in magnocellular neurosecretory cells of the rat supraoptic nucleus. J Physiol 557:949-960.

Brown CH, Ludwig M, Leng G (1998) $\kappa$-Opioid regulation of neuronal activity in the rat supraoptic nucleus in vivo. J Neurosci 18:9480-9488.

Castillo PE, Malenka RC, Nicoll RA (1997) Kainate receptors mediate a slow postsynaptic current in hippocampal CA3 neurons. Nature 388:182-186

Chergui K, Bouron A, Normand E, Mulle C (2000) Functional GluR6 kainate receptors in the striatum: indirect dowregulation of synaptic transmission. J Neurosci 20:2175-2182.

Chittajallu R, Braithwaite SP, Clarke VR, Henley JM (1999) Kaïnate receptors: subunits, synaptic localization and function. Trends Pharmacol Sci 20:26-35.

Clarke VR, Ballyk BA, Hoo KH, Mandelzys A, Pellizzari A, Bath CP, Thomas J, Sharpe EF, Davies CH, Ornstein PL, Schoepp DD, Kamboj RK, Collingridge GL, Lodge D, Bleakman D (1997) A hippocampal GluR5 kainate receptor regulating inhibitory synaptic transmission. Nature 389:599-603.

Cossart R, Esclapez M, Hirsch JC, Bernard C, Ben-Ari Y (1998) GluR5 kainate receptor activation in interneurons increases tonic inhibition of pyramidal cells. Nat Neurosci 1:470-478.

de Kock CP, Wierda KD, Bosman LW, Min R, Koksma JJ, Mansvelder HD, Verhage M, Brussaard AB (2003) Somatodendritic secretion in oxytocin neurons is upregulated during the female reproductive cycle. J Neurosci 23:2726-2734.

Di S, Malcher-Lopes R, Halmos KC, Tasker JG (2003) Nongenomic glucocorticoid inhibition via endocannobinoid release in the hypothalamus: a fast feedback mechanism. J Neurosci 23:4850-4857.

Eyigor O, Centers A, Jennes L (2001) Distribution of ionotropic glutamate receptor subunit mRNAs in the rat hypothalamus. J Comp Neurol 434:101-124.

Fletcher EJ, Lodge D (1996) New developments in the molecular pharmacology of alpha-amino-3-hydroxy-5-methyl-4-isoxazole propionate and kainate receptors. Pharmacol Ther 70:65-89.

Herman JP, Eyigor O, Ziegler DR, Jennes L (2000) Expression of ionotropic glutamate receptor subunit mRNAs in the hypothalamic paraventricular nucleus of the rat. J Comp Neurol 422:352-362.

Higuchi T, Honda K, Fukuoka T, Negoro H, Hosono Y, Nishida E (1983) Pulsatile secretion of prolactin and oxytocin during nursing in the lactating rat. Endocrinol Jpn 30:353-359.

Hirasawa M, Mouginot D, Kozoriz MG, Kombian SB, Pittman QJ (2003) vasopressin differentially modulates non-NMDA receptors in vasopressin and oxytocin neurons in the supraoptic nucleus. J Neurosci 23:4270-4277.

Hirasawa M, Schwab Y, Natah S, Hillard CJ, Mackie K, Sharkey KA, Pittman QJ (2004) Dendritically released transmitters cooperate via autocrine and retrograde actions to inhibit afferent excitation in rat brain. J Physiol 559:611-624.

Huettner JE (2003) Kainate receptors and synaptic transmission. Prog Neurobiol 70:387-407.

Iremonger KJ, Bains JS (2009) Retrograde opioid signaling regulates glutamatergic transmission in the hypothalamus. J Neurosci 29:73497358.

Israel JM, Poulain DA, Oliet SH (2010) Glutamatergic inputs contribute to phasic activity in vasopressin neurons. J Neurosci 30:1221-1232.

Kabashima N, Shibuya I, Ibrahim N, Ueta Y, Yamashita H (1997) Inhibition of spontaneous EPSCs and IPSCs by presynaptic GABAB receptors on rat supraoptic magnocellular neurons. J Physiol 504:113-126.

Kombian SB, Mouginot D, Pittman QJ (1997) Dendritically released peptides act as retrograde modulators of afferent excitation in the supraoptic nucleus in vitro. Neuron 19:903-912.

Lauri SE, Bortolotto ZA, Nistico R, Bleakman D, Ornstein PL, Lodge D, Isaac JT, Collingridge GL (2003) A role for $\mathrm{Ca}^{2+}$ stores in kainate receptordependent synaptic facilitation and LTP at mossy fiber synapses in the hippocampus. Neuron 39:327-341.

Lerma J (2003) Roles and rules of kainate receptors in synaptic transmission. Nat Rev Neurosci 4:481-495.

Liu QS, Han S, Jia YS, Ju G (1999) Selective modulation of excitatory transmission by mu-opioid receptor activation in rat supraoptic neurons. J Neurophysiol 82:3000-3005.

Ludwig M, Sabatier N, Bull PM, Landgraf R, Dayanithi G, Leng G (2002) Intracellular calcium stores regulate activity-dependent neuropeptide release from dendrites. Nature 418:85-89.

Mathew SS, Hablitz JJ (2008) Calcium release via activation of presynaptic IP3 receptors contributes to kaïnate-induced IPSC facilitation in rat neocortex. Neuropharmacology 55:106-116.

Min MY, Rusakov DA, Kullmann DM (1998) Activation of AMPA, kainate, and metabotropic receptors at hippocampal mossy fiber synapses: role of glutamate diffusion. Neuron 21:561-570.

Moll UM, Lane BL, Robert F, Geenen V, Legros JJ (1988) Abundant occurrence of oxytocin-, vasopressin-, and neurophysin-like peptides in epithelial cells. Histochemistry 89:385-390.

Moos F, Freund-Mercier MJ, Guern é Y, Guern é JM, Stoeckel ME, Richard P (1984) release of oxytocin and vasopressin by magnocellular nuclei in vitro: specific facilitatory effect of oxytocin on its own release. J Endocrinol 102:63-72.

More JC, Nistico R, Dolman NP, Clarke VR, Alt AJ, Ogden AM, Buelens FP, Troop HM, Kelland EE, Pilato F, Bleakman D, Bortolotto ZA, Collingridge GL, Jane DE (2004) Characterisation of UBP296: a novel, potent and selective kainate receptor antagonist. Neuropharmacology $47: 46-64$

Oliet SH, Poulain DA (1999) Adenosine-induced presynaptic inhibition of IPSCs and EPSCs in rat hypothalamic supraoptic nucleus neurones. J Physiol 520:815-825.

Pinheiro P, Mulle C (2006) Kainate receptors. Cell Tissue Res 326:457482.

Pinheiro PS, Perrais D, Coussen F, Barhanin J, Bettler B, Mann JR, Malva JO, Heinemann SF, Mulle C (2007) GluR7 is an essential subunit of presynaptic kainate autoreceptors at hippocampal mossy fiber synapses. Proc Natl Acad Sci U S A 104:12181-12186.

Portoghese PS, Lipkowski AW, Takemori AE (1987) Binaltorphimine and nor-binaltorphimine, potent and selective kappa-opioid receptor antagonists. Life Sci 40:1287-1292.

Pow DV, Morris JF (1989) Dendrites of hypothalamic magnocellular neurons release neurohypophysial peptides by exocytosis. Neuroscience 32:435-439.

Price CJ, Pittman QJ (2001) Dopamine D4 receptor activation inhibits pre- 
synaptically glutamatergic neurotransmission in the rat supraoptic nucleus. J Neurophysiol 86:1149-1155.

Schrader LA, Tasker JG (1997) Presynaptic modulation by metabotropic glutamate receptors of excitatory and inhibitory synaptic inputs to hypothalamic magnocellular neurons. J Neurophysiol 77:527-536.

Scott R, Lalic T, Kullmann DM, Capogna M, Rusakov DA (2008) Target-cell specificity of kaïnate autoreceptor and $\mathrm{Ca}^{2+}$-store-dependent short-term plasticity at hippocampal mossy fiber synapses. J Neurosci 28:13139-13149.

Shibuya I, Noguchi J, Tanaka K, Harayama N, Inoue U, Kabashima N, Ueta Y, Hattori Y, Yamashita H (1998) PACAP increases the cytosolic $\mathrm{Ca}^{2+}$ concentration and stimulates somatodendritic vasopressin release in rat supraoptic neurons. J Neuroendocrinol 10:31-42.

Sun HY, Bartley AF, Dobrunz LE (2009) Calcium-permeable presynaptic kainate receptors involved in excitatory short-term facilitation onto so- matostatin interneurons during natural stimulus patterns. J Neurophysiol 101:1043-1055.

van den Pol AN, Hermans-Borgmeyer I, Hofer M, Ghosh P, Heinemann S (1994) Ionotropic glutamate-receptor gene expression in hypothalamus: localization of AMPA, kainate, and NMDA receptor RNA with in situ hybridization. J Comp Neurol 343:428-444.

Vignes M, Collingridge GL (1997) The synaptic activation of kainate receptors. Nature 388:179-182.

Watson SJ, Akil H, Fischli W, Goldstein A, Zimmerman E, Nilaver G, van wimersma Griedanus TB (1982) Dynorphin and vasopressin: common localization in magnocellular neurons. Science 216:85-87.

Whitnall MH, Gainer H, Cox BM, Molineaux CJ (1983) Dynorphin-A(1-8) is contained within vasopressin neurosecretory vesicles in rat pituitary. Science 222:1137-1139. 